\title{
ANALISIS KEMAMPUAN PEMAHAMAN MATEMATIS DAN TINGKAT KEPERCAYAAN DIRI PADA SISWA MTS
}

\author{
Nuraeni $^{1}$, Evon Siti Mulyati ${ }^{2}$, Rippi Maya ${ }^{3}$ \\ 1,2,3 IKIP Siliwangi, Jl. Terusan Jendral Sudirman. Cimahi \\ 1nuraeni8822@gmail.com, ㄹvonsitimulyati@gmail.com, ${ }^{3}$ rippimaya@gmail.com
}

\begin{abstract}
This research is aimed to analyze the mathematical understanding ability and self confidence of MTs students. It is also to analyze the correlation between those two variables. This study used a correelation method with quantitative approach. The reaserch subject are students of MTs in Bandung Barat. With the sample are 18 students of VIII grade. Instruments used in this resarch are mathematical understanding ability test, as many as 5 essay question in each question load one indicator of mathematical understanding ability. There are 20 scale statments taht 4 indicator. The result of this research can be concluded the mathematical comprehension ability and level of selfcompidence students is stin low there is correlation that influence each other between mathematical understanding ability and self confidence of students
\end{abstract}

Keywords: Understanding ability, Self Confidence

\begin{abstract}
Abstrak
Tujuan penelitian ini untuk menganalisis kemampuan pemahaman matematis dan tingkat kepercayaan diri siswa serta diantara hubungan dua variable tersebut. Metode yang digunakan adalah korelasional dengan pendekatan kuantitatif. Populasi dalam penelitian ini adalah siswa MTs di satu sekolah yang ada di kabupaten Bandung Barat dan sampelnya sebanyak 18 orang siswa kelas VIII. Insrumen dalam penelitian ini berupa tes kemampuan pemahaman matematis sebanyak 5 butir soal yang pada setiap satu butir soal memuat satu buah indikator kemampuan pemahaman matematis, dan skala kepercayaan diri siswa terdiri dari 20 skala pernyataan yang termuat dalam 5 buah indikator. Berdasarkan hasil penelitian ini diperoleh kesimpulan bahwa kemampuan pemahaman matematis siswa masih tergolong rendah. Terdapat hubungan yang saling memperngaruhi antara kemampuan pemahaman matematis dan kepercayaan diri siswa.
\end{abstract}

Kata Kunci: Kemampuan Pemahaman Matematis, Kepercayaan Diri

How to cite: Nuraeni, Mulyati, E. S., \& Maya, R. (2018). Analisis Kemampuan Pemahaman Matematis dan Tingkat Kepercayaan Diri pada Siswa MTs. JPMI - Jurnal Pembelajaran Matematika Inovatif, 1 (5), 975-982.

\section{PENDAHULUAN}

Kemampuan pemahaman sangat diperlukan untuk menguasai materi ajar yang memuat banyak rumus agar siswa dapat memahami konsep-konsep dalam materi tersebut secara utuh serta terampil menggunakan berbagai prosedur didalamnya secara fleksibel, akurat, efisien, dan tepat (Dini, 2018). Salah satu tujuan utama pembelajaran matematika di sekolah adalah jika siswa memiliki kemampuan pemahaman matematis yang baik maka siswa tersebut dapat melanjutkan pembelajaran kejenjang yang lebih tinggi.

Kenyataan dilapangan menunjukkan bahwa kemampuan pemahaman matematis siswa masih tergolong rendah. Hal ini sejalan dengan penelitian yang dilakukan Departemen Agama dari 
Zanthy (Dini, 2017)mengatakan bahwa kemampuan pemahaman matematik siswa SMP masih rendah, apalagi siswa MTs yang rata-rata uas matematika lebih rendah dibandingkan di SMP. Selaras dengan penelitian yang dilakukan Mawaddah \& Janah (2016) bahwa sampai saat ini kemampuan pemahaman matematis siswa masih tergolong rendah dimana ada beberapa indikator pemahaman matematis yang belum terpenuhi. Hal ini sejalan dengan Suwarti (Aripin, 2015) bahwa siswa masih mengalami kesulitan pada tingkat kemampuan pemahaman matematik dengan demikian dapat disimpulkan kemampuan pemahaman matematik siswa masih rendah.

Tujuan dalam pendidikan matematika yang dikutip oleh Depdiknas dari KTSP (Anita, 2014)yang terdapat pada poin pertama yaitu siswa memahami konsep matematika, menjelaskan keterkaitan antara konsep dan mengaplikasikan konsep atau algoritma secara luwes, akurat, efisien, dan tepat dalam menyelesaikan masalah. Hal tersebut menunjukkan bahwa siswa harus menguasai pemahaman konsep matematik yang pada akhirnya akan menjadi prasyarat siswa dalam menguasai kemampuan yang lainnya. Menurut Mayer (Nuraeni, 2017) pemahaman merupakan aspek yang fundamental dalam pembelajaran, sehingga model pembelajaran harus menyertakan hal pokok dari pemahaman. Selain itu kemampuan pemahaman digolongkan menjadi dua tingkat menurut Pollatsek dan Skemp (Hendriana \& Sumarmo, 2014) yaitu: (a) Pemahaman instrumental, menghafal konsep tanpa berkaitan dengan yang lainnya, meneruskan rumus dengan perhitungan sederhana, dan mengerjakan perhitungan sesuai algoritmik, serta (b) Pemahaman relasional mengkaitkan satu konsep dengan konsep lainnya.

Selain kemampuan pemahaman matematis, ada aspek afektif yang turut memberikan pemahaman terhadap keberhasilan seseorang dalam menyelesaikan beberapa tugas dengan baik. Salah satu kemungkinan besar yang menjadi penyebab terjadinya kesulitan siswa dalam memahami pembelajaran adalah kurangnya rasa kepercayaan diri siswa dengan kemampuan yang dimilikinya, sehingga siswa merasa rendah diri dan tidak mampu untuk mengerjakan soal yang diberikan oleh guru. Wahyudin (Alan, 2017) menegaskan bahwa selain memiliki kemampuan pemahaman yang baik siswa juga perlu mengenali potensi diri yang mereka miliki untuk membuat target yang akan ditempuh dan dikembangkan dalam kehidupan seharihari siswa yang tercermin dalam sikap percaya diri.

Modal dasar paling utama yang dimiliki dalam diri seseorang untuk bisa mengaktualisasikan diri adalah kepercayaan diri (Komara, 2016). Pengertian kepercayaan diri juga dikemukakan Bandura (Hendriana, Rohaeti \& Sumarmo, 2017) yang mengatakan kepercayaan diri adalah rasa percaya terhadap kemampuan diri dalam menyatukan dan menggerakan (mobilisasi) motivasi dan sumber daya yang dibutuhkan, dalam memunculkan pada tindakan yang tepat dengan harus diselesaikan, sesuai tuntutan tugas.

Berdasarkan permasalahan di atas maka peneliti melakukan sebuah penelitian dengan judul "Analisis Kemampuan Pemahaman Matematis dan Tingkat Kepercayaan Diri Pada Siswa MTs". Adapun rumusan masalahnya adalah:

1. Bagaimana kemampuan pemahaman matematis dan tingkat kepercayaan diri siswa MTs?

2. Apakah terdapat hubungan antara kemampuan pemahaman dengan tingkat kepercayaan diri siswa MTs?

\section{METODE}


Penelitian ini menggunakan metode korelasional dengan pendekatan kuantitatif dengan tujuan mengetahui hubungan kemampuan pemahaman matematis dengan tingkat kepercayaan diri siswa MTs. Subyeknya adalah siswa kelas VIII MTs yang berjumlah 18 orang. Instrumen yang digunakan adalah tes uraian dan non-tes yang berupa skala kepercayaan diri siswa. Data hasil penelitian dianalisis dengan uji korelasi pada Software SPSS 17.0 for windows.

Soal Tes Kemampuan Pemahaman Matematis

Instrumen soal yang digunakan berupa soal uraian pada materi perbandingan yang telah teruji validitasnya, dimana setiap soal memiliki satu indikator pemahaman matematis. Adapun indikator pemahaman matematis menurut Yudhanegara (Pujiani, 2017) yaitu:

(1) Menyatakan ulang sebuah konsep,

(2) Mengklasifikasikan objek menurut tertentu sesuai dengan sifatnya,

(3) Mengidentifikasi contoh dan bukan contoh dari suatu konsep,

(4) Menggunakan dan memanfaatkan serta memilih prosedur atau operasi tertentu, serta

(5) Mengaplikasikan konsep atau algoritma dalam pemecahan masalah.

\section{Skala Kepercayaan Diri}

Skala kepercayaan diri yang digunakan terdiri dari 20 pernyataan yang merupakan modifikasi dari skala kepercayaan diri yang bersumber dari Tamsil (Hendriana, Rohaeti \& Sumarmo, 2017) yang memiliki 4 buah indiktor:

(1)Percaya pada kemampuan Sendiri;

(2)Merasa bebas dan betanggung jawab atas perbuatannya;

(3)Bertindak mandiri dalam mengambil keputusan;

(4)Berani mengemukakan pendapat dan memiliki dorongan untuk berprestasi;

\section{HASIL DAN PEMBAHASAN}

\section{Hasil}

1. Deskripsi dan analisis Kesulitan siswa dalam menyelesaikan soal - soal kemampuan pemahaman matematis

Pemaparan hasil jawaban soal tes kemampuan pemahaman matematis siswa di kelas dapat dilihat dengan presentase skor terhadap SMI yaitu membandingkan nilai rata-rata jawaban perbutir soal dengan skor maksimal perbutir soal dikali 100 persen, dengan kriteria sebagai berikut:

a. Jika presentase skor terhadap SMI lebih dari 50\% maka siswa tersebut tidak mengalami kesulitan dalam menyelesaikan soal-soal kemampuan pemahaman matematis;

b. Jika presentase skor terhadap SMI kurang dari 50\% maka siswa tersebut mengalami kesulitan dalam menyelesaikan soal-soal kemampuan pemahaman matematis.

Menurut Risnawati (Nurwahyudin, 2015) pedoman pemberian skor kemampuan pemahaman sebagai berikut

Tabel 1. Pedoman Penskoran Kemampuan Pemahaman Matematis

\begin{tabular}{clc}
\hline Tingkat Pemahaman & \multicolumn{1}{c}{ Kriteria Penilaian } & Nilai \\
\hline Paham seluruhnya & Jawaban benar dan mengandung seluruh konsep ilmiah & 4 \\
Paham sebagian & Jawaban benar dan mengandung paling sedikit satu konsep & 3 \\
Miskonsepsi sebagian & $\begin{array}{l}\text { ilmiah serta tidak mengandung suatu kesalahan konsep } \\
\text { Jawaban memberikan sebagian informasi yang benar tetapi }\end{array}$ & 2 \\
& juga menunjukan adanya kesalahan konsep dalam
\end{tabular}


978 Nuraeni, Mulyati \& Maya, Analisis Kemampuan Pemahaman Matematis dan Kepercayaan..

\begin{tabular}{lll} 
& menjelaskannya & \\
Miskonsepsi & $\begin{array}{l}\text { Jawaban menunjukan kesalahan pemahaman yang } \\
\text { mendasar tentang konsep yang dipelajari }\end{array}$ & 1 \\
Tidak paham & $\begin{array}{l}\text { Jawaban salah, tidak relevan atau jawaban hanya } \\
\text { mengulang pertanyaan serta jawaban kosong }\end{array}$ & 0 \\
\hline
\end{tabular}
SMI Kemampuan Pemahaman Matematis adalah 20

Tabel 2. Presentase Skor Terhadap SMI Hasil Tes Kemampuan Pemahaman Matematis

\begin{tabular}{clccc}
\hline No soal & \multicolumn{2}{c}{ Indikator Kemampuan Pemahaman Matematis } & Rata-rata & $\%$ \\
\hline 1 & $\begin{array}{l}\text { Menyatakan ulang sebuah konsep } \\
2\end{array}$ & $\begin{array}{l}\text { Mengklasifikasikan objek menurut tertentu sesuai } \\
\text { dengan sifatnya }\end{array}$ & 2,72 & $43,00 \%$ \\
3 & $\begin{array}{l}\text { Mengidentifikasi contoh dan bukan contoh dari suatu } \\
\text { konsep }\end{array}$ & 2,33 & $58,00 \%$ \\
4 & $\begin{array}{l}\text { Menggunakan dan memanfaatkan serta memilih } \\
\text { prosedur atau operasi tertentu }\end{array}$ & 1,50 & $37,50 \%$ \\
5 & $\begin{array}{l}\text { Mengaplikasikan konsep atau algoritma dalam } \\
\text { pemecahan masalah }\end{array}$ & 0,94 & $23,50 \%$ \\
\hline Skor & 1,84 & $46,05 \%$ \\
\hline
\end{tabular}

Dari Tabel 2 diatas soal kemampuan pemahaman matematis pada soal nomor` 1, 4, dan 5 dapat dilihat bahwa presentasenya kurang dari 50\%, sesuai dengan kriteria yang telah dipaparkan diatas, maka siswa mengalami kesulitan dalam menyelesaikan soal-soal kemampuan pemahaman matematis.

Kesalahan siswa dalam mengerjakan soal kemampuan pemahaman matematis pada indikator nomor (1) Menyatakan ulang sebuah konsep, dengan soal sebagai berikut:

"Jarak sebenarnya antara Padalarang dan Cianjur adalah $44 \mathrm{~km}$. Apabila pada peta berskala 1 : 3.000.000 maka jarak kedua kota tersebut adalah?"

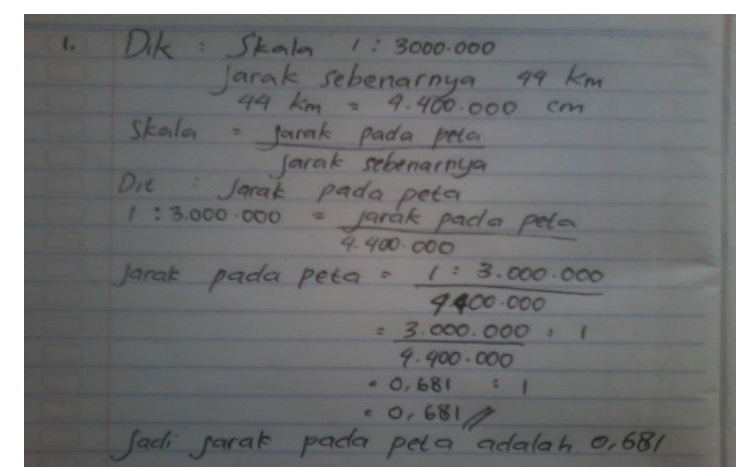

Gambar 1. Kesalahan Siswa Pada Soal Nomor 1

Dari jawaban siswa di atas dapat dianalisis letak kesalahannya yaitu pada cara mereka melakukan operasi penghitungan.

Kesalahan siswa dalam mengerjakan soal kemampuan pemahaman matematis pada indikator nomor (4) Menggunakan dan memanfaatkan serta memilih prosedur atau operasi tertentu, dengan soal sebagai berikut: 
"Siswa kelas VII A sedang melaksanakan ujian matematika di ruang kelasnya. Jika seorang siswa perempuan keluar ruangan, maka $\frac{1}{7}$ dari siswa yang berada di ruangan adalah siswa perempuan. Jika 2 orang siswa laki-laki keluar ruangan maka $\frac{1}{5}$ dari siswa yang berada di ruangan adalah siswa perempuan. Tentukan perbandingan siswa perempuan dan laki-laki! Prosedur apa yang kamu gunakan dalam menyelesaikan permasalahan tersebut?"

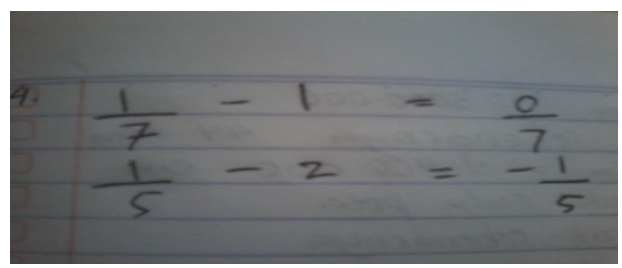

Gambar 2. Kesalahan Siswa Pada Soal Nomor 4

Dari jawaban siswa dapat dianalisis bahwa mereka belum paham dengan apa yang dimaksud dengan pertanyaan yang ada pada soal, sehingga mereka tidak mampu menentukan prosedur yang akan mereka gunakan.

Kesalahan siswa dalam mengerjakan soal kemampuan pemahaman matematis pada indikator nomor (5) Mengaplikasikan konsep atau algoritma dalam pemecahan masalah, dengan soal sebagai berikut:

"Joko dan Badrun berdiri pada satu antrian. Perbandingan banyaknya orang yang mengantri di depan dan di belakang Joko adalah $1: 3$. Sedangkan perbandingan antara banyaknya orang di depan dan di belakang Badrun adalah 2 : 5. Bagaimana kamu menentukan paling sedikit orang pada antrian tersebut?"

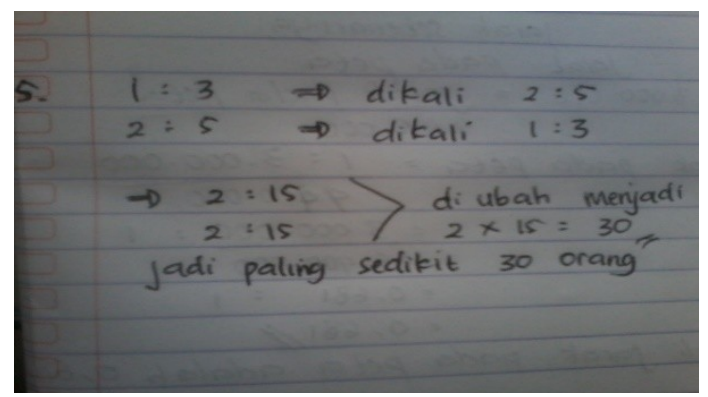

Gambar 3. Kesalahan siswa pada soal nomor 5

Jawaban siswa menunjukkan masih rendah dalam mengaplikasikan konsep serta tidak dapat memahami apa yang dimaksud dengan pertanyaan yang ada pada soal.

\section{Deskripsi Hasil dan Analisis Kepercayaan Diri Siswa}

Pemaparan hasil jawaban angket skala kepercayaan diri siswa di kelas dapat dilihat dengan presentase skor terhadap SMI yaitu membandingkan nilai rata-rata jawaban perindikator dengan skor maksimal perbutir pernyataan dikali 100 persen, dengan kriteria sebagai berikut:

a. Jika presentase skor terhadap SMI lebih dari 50\% maka siswa tersebut percaya diri akan kemampuan yang dimilikinya; 
b. Jika presentase skor terhadap SMI kurang dari 50\% maka siswa tersebut tidak percaya diri akan kemampuan yang dimilikinya.

Tabel 3. Hasil Tes Kepercayaan Diri

\begin{tabular}{clcc}
\hline No soal & \multicolumn{1}{c}{ Indikator Skala Kepercayaan Diri } & Rata-rata & $\%$ \\
\hline 1 & Percaya kepada kemampuan sendiri & 1,66 & $41,50 \%$ \\
2 & Bertindak mandiri dalam mengambil keputusan & 2,36 & $59,00 \%$ \\
3 & Menunjukan sikap positif dalam menghadapi masalah & 2,52 & $63,00 \%$ \\
4 & Berani mengungkapkan pendapat & 2,42 & $60,50 \%$ \\
\hline & Skor & 2,24 & $56,00 \%$ \\
\hline
\end{tabular}

SMI Skala Kepercayaan Diri Siswa adalah 80

Berdasarkan Tabel 3 menunjukkan hasil presentase skala kepercayaan diri siswa pada indikator nomor 1 berada dibawah 50\% maka dapat dideskripsikan bahwa masih ada siswa yang tidak percaya diri akan kemampuan yang dimilikinya.

\section{Uji Korelasi antara Kemampuan Pemahaman Matematis dan Kepercayaan Diri Siswa}

Kemudian dilakukan uji korelasi untuk mengetahui hubungan antara kemampuan pemahaman matematis dengan tingkat kepercayaan diri siswa, dengan hasil pengujian disajikan pada Tabel 4 berikut.

Tabel 4. Hasil Correlations

\begin{tabular}{llrr}
\hline & & $\begin{array}{l}\text { Kemampuan } \\
\text { Pemahaman Matematis }\end{array}$ & \multicolumn{2}{c}{$\begin{array}{c}\text { Kepercayaan } \\
\text { Diri }\end{array}$} \\
\hline Kemampuan & Pearson & 1 & $.926^{* *}$ \\
Pemahaman Matematis & Correlation & & \\
& Sig. (2-tailed) & 18 & .000 \\
& N & $.926^{* *}$ & 18 \\
Kepercayaan Diri & Pearson & & 1 \\
& Correlation & .000 & \\
& Sig. (2-tailed) & 18 & 18 \\
\hline
\end{tabular}

Berdasarkan nilai signifikansi dari output di atas diketahui bahwa kemampuan pemahaman matematis dengan tingkat kepercayaan diri memiliki nilai signifikansi 0,000 artinya nilai tersebut $<0,05$ maka dapat dikatakan bahwa terdapat hubungan antara kemampuan pemahaman matematis dengan kepercayaan diri siswa dan dapat diketahui pula dari nilai pearson correlation adalah 0,926 artinya dapat disimpulkan bahwa kepercayaan diri siswa berpengaruh secara positif terhadap kemampuan pemahaman matematis.

\section{Pembahasan}

Dari hasil analisis data penelitian terlihat pada Tabel 2 diatas soal kemampuan pemahaman matematis pada soal nomor 1 dengan indikator menyatakan ulang sebuah konsep, presentase 
ketuntasannya 43,00\%. Soal nomor 2 dengan indikator mengklasifikasikan objek menurut tertentu sesuai dengan sifatnya, presentase ketuntasannya 68,00\%. Soal nomor 3 dengan indikator mengidentifikasi contoh dan bukan contoh dari suatu konsep, presentase ketuntasannya 58,25\%. Soal nomor 4 dengan indikator menggunakan dan memanfaatkan serta memilih prosedur atau operasi tertentu, presentase ketuntasannya 37,50\%. Soal nomor 5 dengan indikator mengaplikasikan konsep atau algoritma dalam pemecahan masalah, presentase ketuntasannya $23,50 \%$.

Berdasarkan hasil pemaparan diatas dapat dilihat bahwa presentase pada indikator nomor 1, 4 dan 5 berada di bawah $50 \%$ dan indikator nomor 2 dan 3 berada diatas 50\%. Dari 5 soal yang disajikan ternyata terdapat 3 soal yang membuat siswa masih kesulitan untuk mengerjakannya. Artinya masih banyak siswa yang mengalami kesulitan dalam menyelesaikan soal kemampuan pemahaman matematis tersebut.

Hasil jawaban siswa pada Gambar 1, terlihat siswa terlalu yakin dengan jawaban yang dikerjakannya, sehingga siswa kurang tepat dalam melakukan operasi penghitungan dan tidak mengecek ulang hasil yang telah dikerjakannya. Pada Gambar 2 terlihat hasil jawaban siswa tidak memahami pertanyaan yang ada pada soal, sehingga siswa tersebut tidak dapat menentukan prosedur untuk menyelesaikan soal dan tidak percaya diri dengan kemampuan yang dimilikinya. Selanjutnya pada Gambar 3 terlihat siswa tidak dapat mengaplikasikan konsep, sehingga jawabah mereka tidak tepat dan terlihat tidak yakin dengan kemampuannya. Hal tersebut sesuai dengan Hidayat (Dini, 2018)mengatakan bahwa siswa tersebut kurang teliti dan tidak percaya diri yang mengakibatkan daya juang dalam menghadapi masalah yang sangat lemah. Hal ini dikarenakan siswa yang memiliki daya juang yang lemah dalam menghadapi masalah akan mengakibatkan hasil yang kurang optimal, sehingga pada akhirnya tidak yakin akan hasil yang sedang dihadapinya.

Analisis berikutnya adalah untuk melihat hubungan antara kemampuan pemahaman matematis dengan kepercayaan diri siswa. Berdasarkan hasil uji korelasi dapat disimpulkan bahwa kepercayaan diri siswa berhubungan secara positif terhadap kemampuan pemahaman matematis. Senada dengan penelitan yang dilakukan oleh Purwasih (2015) dalam jurnal penelitiannya, menyimpulkan bahwa terdapat hubungan positif antara Self Confidence dan kemampuan pemahaman. Hal ini terlihat dari nilai untuk kelas kontrol bernili positif sebesar 0,225 dan nilai korelasi untuk kelas eksperimen sebesar 0, 123. Oleh karena itu Self Confidence siswa harus diatasi agar kemampuan pemahaman matematis siswa dapat berkembang dengan baik.

Menurut Warman (Efendi, 2016) bahwa tingkat hasil kepercayaan diri dipengaruhi oleh percaya diri siswa tinggi dan sebaliknya rendah hasil kepercayaan diri diengaruhi oleh rendahnya percaya diri siswa itu sendriri. Berkaitan dengan hasil penelitian yang dilakukan Hidayat (Dini, 2018) menunjukkan bahwa siswa yang memiliki Self Confidence tinggi dapat membentuk keyakinan pada dirinya tentang kemampuan untuk pantang menyerah dalam menghadapi permasalahan yang diberikan.

\section{KESIMPULAN}

Berdasarkan hasil penelitian dan analisis yang dilakukan mengenai hubungan kemampuan pemahamanmatematis dengan tingkat kepercayaan diri siswa MTs diperoleh kesimpulan sebagai berikut: 
982 Nuraeni, Mulyati \& Maya, Analisis Kemampuan Pemahaman Matematis dan Kepercayaan..

1. Kemampuan pemahaman matematis siswa masih tergolong rendah, terlihat dari 5 indikator kemampuan pemahaman matematis, 3 diantaranya masih belum bisa terpenuhi yaitu indikator nomor 1, 4 dan 5. Sedangkan untuk kepercayaan diri menunjukan siswa masih lemah pada indikator nomor 1 .

2. Terlihat dari hasil uji korelasi bahwa terdapat hubungan secara positif terhadap kepercayaan diri siswa dengan kemampuan pemahaman matematis.

\section{DAFTAR PUSTAKA}

Alan, U. F., A. E. A. (2017). Kemampuan Pemahaman Matematis Siswa Melalui Model Pembelajaran Audiotory Intellectualy Repetition Dan Problem Based Learning. Jurnal Pendidikan Matematika, 11 nomor 1.

Anita, I. W. (2014). Pengaruh Kecemasan Matematika (Mathematics Anxiety) terhadap Kemampuan Koneksi Matematika (SMP). Infinity Jurnal Ilmiah, 3(1). Retrieved from ejournal.stkipsiliwangi.ac.id

Aripin, U. (2015). Meningkatkan Kemampuan Pemahaman Matematik Siswa SMP Melalui Pendekatan Pembelajaran Berbasis Masalah. P2M STKIP Siliwangi, 2.

Dini, M. (2017). Analisis Kemmpuan Pemahaman Matematik Siswa SMP Di Kota Cimahi Pada Materi Segitiga Dan Segiempat. Prosiding Seminar Nasional Matematika Dan Pendidikan Matematika STKIP Siliwangi, 5, 1145-1150.

Dini, M. (2018). Pengaruh Self Confidence Terhadap Kemampuan Pemahman Matematik Siswa SMP. Jurnal Silogisme, 1(3), 1-7.

Efendi, D. Y. (2016). Meningkatkan Kemampuan dan Koneksi Serta Kepercayaan Diri Matematik Siswa SMP mealui Pendekatan Generatif.

Hendriana, H., Rohaeti, E, S., \& Sumarmo, U. (2017). Hard Skill dan Soft Skill. Bandung: Refika Aditama.

Hendriana, H., Sumarmo, U. (2014). Penilaian Pembelajaran Matematika. Bandung: Refika Aditama.

Komara, I. B. (2016). Hubungan antara Kepercayaan Diri dengan Prestasi Belajar dan Perencanaan Karir Siswa, 5(1), 33-42.

Mawaddah, S., Janah, R. (2016). Meningkatkan Kemampuan Pemahaman Matematis Siswa Dengan Model Pembelajaran Quantum Teaching Di Kelas XI SMA. EDU-MAT Jurnal Pendidikan Matematika, 4 nomor 2.

Nuraeni, R. (2017). P ERBANDINGAN K EMAMPUAN P EMAHAMAN M ATEMATIS S ISWA A NTARA Y ANG M ENGGUNAKAN P EMBELAJARAN I NSIDE -O UTSIDE - $T$ HE $C$ OMPARISON OF $S$ TUDENTS ' $M$ ATHEMATICAL U NDERSTANDING BETWEEN, 6(September), 441-450.

Nurwahyudin, D. S. (2015). Pengaruh Pendekatan Kontekstual Terhadap Kemampuan Pemahaman Matematis Siswa SMP. Skripsi STKIP Siliwangi Bandung.

Pujiani. (2017). Meningkatkan Kemampuan Pemahaman Matematis Siswa SMK dengan menggunakan Pendekatan Kontekstual. Skripsi STKIP Siliwangi Bandung.

Purwasih, R. (2015). Peningkatan Kemampuan Pemahaman Matematis dan Self Confidence Siswa MTs Di Kota Cimahi Melalu Model Pembelajaran Inkuiri Terbimbing. Jurnal Ilmiah STKIP Siliwangi Bandung, 9(1), 16. 